\title{
BRPKM
}

Buletin Riset Psikologi dan Kesehatan Mental

http://e-journal.unair.ac.id/index.php/BRPKM

e-ISSN: 2776-1851

ARTIKEL PENELITIAN

\section{Pengaruh Self-Esteem dan Penerimaan Kekerasan dalam Pacaran terhadap Dating Violence Victimization pada Remaja Perempuan}

\author{
ANDI SABRINA QAMARANI BACHTIAR \& NURUL HARTINI* \\ Fakultas Psikologi Universitas Airlangga
}

\begin{abstract}
ABSTRAK
Penelitian ini bertujuan untuk mengetahui pengaruh antara self-esteem dan penerimaan kekerasan dalam pacaran terhadap dating violence victimization pada remaja perempuan. Menjalankan hubungan pacaran yang positif dan sukses merupakan salah satu tugas perkembangan remaja yang membantu perkembangan remaja ke arah yang lebih positif. Namun masih banyak terjadi dating violence victimization. Oleh karena itu, penelitian ini bertujuan untuk mengetahui apakah terdapat pengaruh dari self-esteem dan penerimaan kekerasan dalam pacaran terhadap kerentanan dating violence victimization. Metode penelitian dalam penelitian ini adalah metode kuantitatif melalui survei. Dari hasil analisis ditemukan bahwa adanya pengaruh antara self-esteem dan penerimaan kekerasan dalam pacaran terhadap dating violence victimzation baik secara parsial maupun secara simultan pada remaja perempuan. Dari hasil ini maka dapat disimpulkan bahwa perlunya memiliki self-esteem yang positif dan penerimaan kekerasan dalam pacaran yang negatif untuk menurunkan kerentanan dating violence victimization.
\end{abstract}

Kata kunci: penerimaan, kekerasan pacaran, self-esteem, victimization

\begin{abstract}
This study aims to determine the effect of self-esteem and acceptance of dating violence on dating violence victimization among female adolescents. Having positive and successful dating relationships is one of the tasks of adolescent development that helps adolescent development in a more positive direction. However, there are still many dating violence victimization occurrences. Therefore, this study aims to determine whether there is an effect of self-esteem and acceptance of dating violence on the susceptibility of dating violence victimization. The research method in this research is a quantitative method through a survey. From the analysis, it is found that there is an influence between self-esteem and acceptance of dating violence on dating violence victimization both partially and simultaneously in young girls. From these results, it can be concluded that the need to have positive self-esteem and a negative acceptance of dating violence to reduce the susceptibility of dating violence victimization.
\end{abstract}

Keywords: acceptance, dating violence, self-esteem, victimization

Buletin Penelitian Psikologi dan Kesehatan Mental (BRPKM), 2021, Vol. 1(1), 705-714

*Alamat korespondensi: Fakultas Psikologi Universitas Airlangga, Kampus B Universitas Airlangga Jalan

Airlangga 4-6 Surabaya 60286. Surel: nurul.hartini@psikologi.unair.ac.id 
Naskah ini merupakan naskah dengan akses terbuka dibawah ketentuan the Creative Common Attribution License (CC-BY-4.0) (http://creativecommons.org/licenses/by/4.0), sehingga penggunaan, distribusi, reproduksi dalam media apapun atas artikel ini tidak dibatasi, selama sumber aslinya disitir dengan baik.

\section{PEN D A H U L U A N}

Remaja merupakan tahap perkembangan yang tak terlupakan dalam hidup seseorang, (Santrock, 2012) mendefinisikan remaja sebagai sebuah fase perkembangan transisi dalam rentang hidup manusia. Fase transisi tersebut menghubungkan masa kanak-kanak dan masa dewasa. Perubahan sosial yang terjadi pada masa remaja salah satunya merupakan keinginan untuk menjalin hubungan romantis atau seksual, hal ini disebabkan remaja akan mulai memiliki rasa ketertarikan secara romantis dengan lawan jenisnya. Hubungan romantis yang sukses umumnya dianggap sebagai salah satu tugas perkembangan utama remaja dan transisi ke masa dewasa (Conger, Cui, Bryant, \& Elder, 2000 dalam Cascardi \& Jouriles, 2018). Di Indonesia sendiri menurut SDKI tahun 2017, 80\% perempuan berumur 15-24 tahun sedang menjalani pacaran, dan baru memulai hubungan pacaran pada umur 15-17 tahun. Sehingga dapat dikatakan bahwa kebanyakan perempuan remaja di Indonesia menjalani hubungan pacaran.

Masa remaja dan dewasa awal menurut sudut pandang evolusi merupakan masa yang sangat penting dalam pengembangan hubungan romantis. Pada tahap remaja pertengahan, kebanyakan anak laki-laki dan perempuan terlibat dalam setidaknya satu hubungan pacaran. Hubungan pacaran tersebut memberikan mereka suatu situasi yang ditandai dengan keintiman yang lebih besar, dukungan, dan rasa dipentingkan seiring dengan bertambahnya usia mereka. Hubungan pacaran adalah sumber penting dari ikatan emosional dan berkontribusi terhadap pengembangan konsep diri yang positif dan integrasi sosial yang lebih besar. Karena itu pembentukan dan pemeliharaan hubungan pacaran yang berhasil memiliki dampak penting di tahap kehidupan selanjutnya (Gómez-López dkk., 2019). Berbagai penelitian telah menjelaskan tentang dampak positif dari menjalankan hubungan pacaran, salah satunya penelitian yang dilakukan Gómez-López dkk., (2019) yang menunjukkan hubungan pacaran yang memiliki kualitas positif dapat meningkatkan well-being pada remaja dan dewasa awal.

Namun kenyataannya masih banyak hubungan pacaran yang memiliki kualitas negatif yang ditandai dengan kekerasan dalam pacaran (dating violence) terutama pada masa remaja. Kekerasan dalam pacaran didefinisikan oleh Wolfe dan Feiring (2000, dalam Trifiani, 2012) sebagai segala usaha untuk mengontrol pasangan romantis secara fisik, seksual, atau psikologis yang dapat mengakibatkan luka atau kerugian. Taylor dan Mumford (2014, dalam Mendoza \& Mulford, 2018) melakukan penelitian yang menunjukkan persentase besar dari remaja yang berpacaran melaporkan mengalami kekerasan fisik (18\%), psikologis (60\%), atau seksual (18\%) dalam hubungan mereka dalam tahun sebelumnya. Kemudian di Indonesia, menurut CATAHU yang dilakukan Komnas Perempuan (2020) menunjukkan bahwa terdapat lebih dari 1500 kasus kekerasan dalam pacaran. Bahkan untuk angka pelaku kekerasan seksual di Indonesia terbanyak adalah pacar dengan 1320 kasus tahun ini, yang secara konsisten tetap di posisi teratas sejak 3 tahun lalu sehingga dirasa menarik untuk mengkaji fenomena kekerasan dalam pacaran ini.

Bila membahas kekerasan dalam pacaran, penelitian terdahulu cenderung membedakan fokus pada prepetrator atau pelaku dan victim atau korban kekerasan dalam pacaran. Dapat dilihat dari data yang telah dijelaskan sebelumnya, dating violence victimization merupakan masalah sosial yang meluas. Dating violence victimization adalah keadaan di mana individu mendapatkan tindak kekerasan dalam pacaran dari pasangannya (Capaldi dan Crosby, 1997 dalam Kaura \& Lohman 2007). Korban (victim) kekerasan dalam pacaran tidak hanya berupa korban dari kekerasan fisik tetapi juga korban dari 
kekerasan seksual dan juga kekerasan psikologis/verbal. Viktimisasi kekerasan dalam pacaran bisa saja terjadi pada laki-laki ataupun perempuan. Namun, menurut Karlsson (2011) yang telah mengulas berbagai penelitian terdahulu mengenai viktimisasi kekerasan dalam pacaran dan perbedaan jenis kelamin menunjukkan bahwa perempuan muda lebih mungkin menjadi korban kekerasan dalam pacaran, dan melaporkan kekerasan yang lebih parah, serta memiliki lebih banyak cedera dibandingkan laki-laki.

Menurut Semaan (2004 dalam Pereira dkk., 2020) pertanyaan yang sering dilontarkan masyarakat terkait dating violence victimization merupakan "Mengapa mereka tetap bertahan pada hubungan tersebut?" atau "Mengapa mereka tidak pergi?", pertanyaan-pertanyaan ini dapat dijawab dengan melihat faktor-faktor penyebab korban kekerasan dalam pacaran bertahan pada hubungan yang disertai kekerasan. Menurut faktor dating violence victimization yang dijelaskan oleh O'Keefe \& Treister (1998) salah satu faktor yang mempengaruhi korban tetap bertahan pada hubungan yang disertai kekerasan adalah tingkat self-esteem yang dimiliki. Rosenberg (1965) yang merupakan salah satu pencetus pemikiran self-esteem menjelaskan bahwa self-esteem berfokus pada evaluasi individu dari keseluruhan aspek mengenai dirinya sendiri. Jika seseorang yang memiliki self-esteem yang negatif akan semakin rentan kemungkinan mereka untuk menjadi victim dalam dating violence. Putri (2012) menemukan bahwa korban kekerasan dalam pacaran cenderung melaporkan self-esteem yang negatif. Penelitian selanjutnya dilakukan oleh Papadakaki dkk., (2009) yang menunjukkan terdapat hubungan signifikan antara self-esteem dan dating violence baik prepetrator atau victimization.

Faktor dating violence victimization lain yang O'Keefe \& Treister (1998) jelaskan adalah sifat penerimaan kekerasan dalam pacaran, yaitu sikap yang mendukung mengapa remaja perempuan bertahan pada hubungan pacaran yang disertai kekerasan. Istilah penerimaan kekerasan disamakan dengan sikap seseorang terhadap pembenaran, atau toleransi seseorang terhadap kekerasan. (Foshee dkk. 2001; O’Keefe dan Treister 1998 dalam Kaura \& Lohman, 2007). Penelitian telah menemukan bahwa remaja yang melaporkan penerimaan kekerasan dalam pacaran lebih cenderung melaporkan sebagai perpetrator ataupun victim dari kekerasan dalam pacaran (Malik dkk., 1997 dalam Karlsson dkk., 2016). Penelitian yang dilakukan oleh Price dan Byers tahun 1999 dalam Karlsson dkk., (2018) menunjukkan Remaja dan dewasa muda yang telah mengalami kekerasan dalam pacaran lebih menerima kekerasan dalam pacaran dibandingkan individu tanpa pengalaman tersebut. Temuan ini sangat menarik untuk mengetahui mengapa korban (victim) kekerasan dalam pacaran tidak mengakhiri hubungan mereka atau meninggalkan pelakunya.

Masa remaja merupakan masa yang penting untuk perkembangan individu yang diharapkan mampu mencapai tugas perkembangannya, memiliki hubungan pacaran yang positif merupakan salah satu ciri khas pada tugas tahap perkembangan remaja yang dapat memberikan meningkatkan well-beingnya dan memberikan motivasi (Gómez-López dkk., 2019). Apabila remaja memiliki hubungan pacaran yang negatif dengan disertai kekerasan dalam pacaran, maka akan muncul hambatan pada tahapan perkembangannya tersebut, terlebih apabila remaja tidak dapat pergi dari hubungan viktimisasi kekerasan dalam pacaran yang dikarenakan tingkat self-esteem yang negatif dan tingkat penerimaan kekerasan dalam pacaran yang positif, mereka akan mengalami berbagai dampak negatif yang telah dijelaskan diatas. Karena ini, masalah dari penelitian ini adalah untuk dapat mengetahui apakah ada pengaruh antara self-esteem dan penerimaan kekerasan dalam pacaran terhadap dating violence victimization pada remaja perempuan. 


\section{Desain Penelitian}

\section{E T O D E}

Jenis penelitian yang digunakan dalam penelitian ini adalah menggunakan pendekatan kuantitatif dengan survei. Pada penelitian ini peneliti menggunakan tiga variabel yaitu self-esteem dan penerimaan kekerasan dalam pacaran sebagai variabel independen dan dating violence victimization sebagai variabel dependen. Agar sesuai dengan tujuan penelitian, ketiga variabel tersebut akan diuji untuk mengetahui pengaruh antara kedua variabel independen terhadap variabel dependen baik secara parsial ataupun simultan. Berdasarkan dimensi waktu, penelitian ini masuk ke dalam tipe crosssectional di mana penelitian hanya dilakukan dalam waktu tertentu.

\section{Partisipan}

Penelitian ini menggunakan teknik sampling non-probability sampling dengan metode purposive sampling. Beberapa karakteristik yang harus dipenuhi untuk menjadi partisipan dalam penelitian ini adalah berusia 14-19 tahun, memiliki jenis kelami perempuan, dan pernah atau sedang menjalani hubungan romantis atau pacaran yang disertai kekerasan, berdomisili di Jakarta. Penelitian ini menentukan jumlah minimal partisipan yang dibutuhkan dalam penelitian ditentukan dengan menggunakan aplikasi $G^{*}$ Powers 3.1.9.2. Teknik statistikal yang digunakan adalah correlation: point biserial model dengan menggunakan tipe a priori analysis: computed requires sample size-given alpha, power, and effect size. Dengan menggunakan teknik tersebut dengan mendeteksi effect size sebesar 0,20 yang tergolong medium dengan statistical power sebesar $80 \%$ dan alpha sebesar 5\%. Dari hasil penghitungan tersebut, menghasilkan jumlah partisipan minimal dari penelitian ini adalah sebanyak 150 partisipan, namun untuk menguji hipotesis penelitian ini, peneliti merekrut 157 partisipan $\left(M_{\text {usia }}=17,9 ; S D_{\text {usia }}=1,449\right)$ dengan mayoritas partisipan berusia 19 tahun.

\section{Pengukuran}

Alat ukur yang digunakan dalam penelitian ini berupa kuesioner yang berisi identitas umur partisipan, selanjutnya terdapat tiga skala untuk mengukur masing-masing variabel self-esteem, penerimaan kekerasan dalam pacaran, dan dating violence victimization. Variabel self-esteem diukur menggunakan Rosenberg Self-Esteem Scale (RSES) yang telah diadaptasi ke dalam Bahasa Indonesia oleh Fatah (2020) RSES memiliki jumlah pernyataan aitem sebanyak 10 pernyataan yang terdiri dari masing-masing 5 aitem favorable dan unfavorable. Alat ukur tersebut menggunakan skala likert dengan empat alternatif jawaban. Selain itu, alat ukur RSES memiliki koefisien reliabilitas sebesar 0,757 sehingga dapat dikatakan bahwa alat ukur ini sangat reliabel untuk mengukur variabel self-esteem. Untuk mengukur variabel penerimaan kekerasan dalam pacaran penelitian ini peneliti menerjemahkan alat ukur Attitudes Towards Male Dating Violence (ADMV) yang telah dilakukan validasi oleh expert judges. Alat ukur ini memiliki jumlah pertanyaan 39 pernyataan yang terdiri dari lima alternatif jawaban. ADMV ini memiliki reliabilitas sebesar 0,827 sehingga dikatakan alat ukur ini reliabel untuk mengukur penerimaan kekerasan dalam pacaran. Sedangkan untuk variabel dating violence victimization menggunakan alat ukur The Revised Conflict Tactics Scale (CTS2) yang sudah diterjemahkan oleh Rasyidayanti (2018). Alat ukur ini terdiri dari 39 pernyataan yang terdiri dari delapan alternatif jawaban. CTS2 ini memilki reliabilitas sebesar 0,927 sehingga dapat dikatakan CTS2 dapat mengukur dating violence victimization. 
Peneliti melakukan berbagai uji untuk menentukan teknik statistik yang nantinya akan digunakan, baik teknik statistik parametrik atau non-parametrik. Uji pertama yang dilakukan merupakan uji asumsi yang menghasilkan data berdistribusi secara normal dengan melihat skewness dan kurtosis masingmasing variabel yang menunjukkan angka dari 2 hingga +2 . Uji kedua merupakan uji linearitas, yang menghasilkan kedua variabel independen pada variabel dependen dalam penelitian yang melihat dari nilai signifikansi linearitas keduanya $p<0,05$ dan nilai deviasi linearitas $p>0,05$. Sehingga dapat dikatakan terdapat hubungan yang linear setiap variabel independen terhadap variabel dependen. Selanjutnya peneliti melakukan uji multikolinearitas, dari hasil uji multikolinearitas terlihat nilai tolerance melebihi 0,1 dengan nilai 0,989 dan nilai VIF kurang dari 10 dengan nilai 1,011. Dari penjelasan berikut menunjukkan bahwa tidak terjadinya multikolinearitas antar kedua variabel independen. Uji berikutnya merupakan uji heteroskedastisitas. Berdasarkan grafik scatterplot pada gambar 4.7 menunjukkan bahwa tidak adanya pola tertentu seperti gelombang, melebar kemudian menyempit, dan lain-lain. Maka dari itu, dapat dikatakan bahwa tidak adanya atau tidak terjadinya gejala heteroskedastisitas, yang berarti bahwa tingkat varians eror relatif konstan untuk masing-masing nilai prediksi. Sehingga peneliti menggunakan teknik statistik parametrik yaitu uji regresi linear sederhana dan uji regresi linear berganda.

\section{Analisis Data}

Teknik analisis data yang digunakan dalam penelitian ini adalah teknik korelasi Pearson Product Moment dengan menggunakan bantuan perangkat lunak SPSS for Mac versi 22.

\section{HAS IL P EN ELIT IAN}

Hasil analisis deskriptif menunjukkan bahwa jumlah partisipan dalam penelitian ini (N) sebanyak 157 subjek yang selanjutnya akan dianalisis pada tiap variabel penelitian yang merupakan self-esteem, penerimaan kekerasan dalam pacaran, dan dating violence victimization. Terlihat pada variabel selfesteem mendapat nilai terendah sebesar 10 poin dan nilai tertinggi sebesar 34 poin, kemudian memiliki mean sebesar 24,02 . Variabel berikutnya yaitu penerimaan kekerasan dalam pacaran mendapat nilai terendah 45 poin dan nilai tertinggi sebesar 139 poin, dengan mean 82,69. Selanjutnya pada variabel dating violence victimization mendapat nilai terendah 55 poin dan nilai tertinggi 198 poin dengan mean 96,75 . Untuk standar deviasi variabel self-esteem adalah 4,682, untuk variabel penerimaan kekerasan dalam pacaran 17,575, untuk variabel dating violence victimization 32,211. Berikutnya, melihat skewness dan kurtosis variabel self-esteem memiliki nilai skewness -0,137 dan kutosis -0,447. Selanjutnya pada variabel penerimaan kekerasan dalam pacaran memiliki skewness sebesar 0,677 dan kurtosis sebesar 0,823. Pada variabel terakhir yaitu dating violence victimization memiliki nilai skewness sebesar 1,354 dan kurtosis sebesar 0,987.

Hasil analisis regresi linear sederhana antara self-esteem terhadap dating violence victimization pada remaja perempuan, nilai signifikansi variabel self-esteem adalah sebesar 0,007. $R$ Square memiliki nilai 0,046 . Sehingga menunjukkan besarnya pengaruh self-esteem terhadap dating violence victimization adalah sebesar 4,6\% dan 95,4\% pengaruh lainnya berasal dari faktor lain yang tidak diteliti di penelitian ini. Selanjutnya nilai a atau nilai konstanta variabel dependen dating violence victimization sebesar 132,165 . Sedangkan untuk nilai b yang merupakan nilai koefisian regresi bernilai -1,474. Self-esteem secara signifikan berpengaruh dengan sifat negatif terhadap dating violence victimization pada remaja perempuan.

Hasil analisis regresi linear sederhana antara penerimaan kekerasan dalam pacaran terhadap dating violence victimization pada remaja perempuan, nilai signifikansi variabel penerimaan kekerasan dalam 
pacaran adalah sebesar $0,001 . R$ Square memiliki nilai 0,066 . Sehingga menunjukkan besarnya pengaruh penerimaan kekerasan dalam pacaran terhadap dating violence victimization adalah sebesar 6,6\% dan 93,4\% pengaruh lainnya berasal dari faktor lain yang tidak diteliti di penelitian ini. Selanjutnya untuk nilai a atau nilai konstanta variabel dependen dating violence victimization sebesar 57,795. Sedangkan untuk nilai b yang merupakan nilai koefisien regresi bernilai 0,471. Penerimaan kekerasan dalam pacaran secara signifikan berpengaruh dengan sifat positif terhadap dating violence victimization pada remaja perempuan.

Hasil analisis regresi linear berganda antara self-esteem dan penerimaan kekerasan dalam pacaran terhadap dating violence victimization pada remaja perempuan, nilai signifikansi sebesar 0,000. Kemudian $\mathrm{R}$ dalam model regresi adalah 0,319 kemudian nilai $R$ Square menunjukkan angka 0,102. Sehingga $R$ Square menunjukkan besarnya pengaruh self-esteem dan penerimaan kekerasan dalam pacaran terhadap dating violence victimization adalah sebesar $10,2 \%$. Selanjutnya, nilai $\mathrm{F}$ hitung dengan F tabel. Diketahui dari tabel $4.18 \mathrm{~F}$ hitung adalah sebesar 8,723 dan F tabel = 2;155 atau F tabel 3,05. Maka dalam penelitian ini $\mathrm{F}$ hitung 8,723 > F tabel 3,05. Kedua variabel independen self-esteem dan penerimaan kekerasan dalam pacaran mempengaruhi dating violence victimization secara simultan.

\section{I S K U S I}

Penelitian ini memiliki tujuan untuk mengetahui apakah adanya pengaruh secara signifikan antara selfesteem dan penerimaan kekerasan dalam pacaran terhadap dating violence victimization pada remaja perempuan di Jakarta. Penelitian ini dilakukan secara online dengan melibatkan 157 subjek dengan rentang usia 14-19 tahun, pernah atau sedang mengalami kekerasan dalam pacaran, berdomisili di Jakarta. Subjek pengisi penelitian ini mayoritas berusia 19 tahun yaitu 50,9\% dari total partisipan. Peneliti telah melakukan serangkaian analisis dan menunjukkan hasil bahwa kedua variabel independen self-esteem dan penerimaan kekerasan dalam pacaran memiliki pengaruh terhadap variabel dependen dating violence victimization baik secara parsial maupun simultan dengan sifat yang berbeda.

Hasil dari uji regresi linear sederhana, variabel self-esteem yang menunjukkan bahwa self-esteem dan dating violence victimization memiliki pengaruh signifikan secara negatif antara dua variabel tersebut. Dengan kata lain, semakin rendah nilai self-esteem maka semakin tinggi dating violence victimization begitupun sebaliknya. Artinya apabila seseorang memiliki self-esteem yang negatif maka akan semakin rentan menjadi korban (victim) pada kekerasan dalam pacaran. Hal ini sejalan dengan teori yang mengatakan apabila seseorang mengalami self-esteem yang positif maka mereka akan lebih mungkin untuk memisahkan diri dari viktimisasi dan dapat tidak menyamakan dengan masalah pemikiran negatif mengenai dirinya (Kaura \& Lohman, 2009) Selanjutnya apabila seseorang memiliki self-esteem yang negatif mereka akan lebih rentan terhadap dating violence victimization karena akan muncul penolakan diri, penghinaan terhadap diri, ketidakpuasan, dan kurangnya penghargaan terhadap diri sendiri (Rosenberg, 1965) Hasil penelitian ini konsisten dengan penelitian yang dilakukan oleh (Putri, 2012) yang menunjukkan pengaruh self-esteem dengan kekerasan dalam pacaran, dimana menghasilkan semakin negatifnya self-esteem maka semakin rentan kekerasan dalam pacaran.

Hasil uji regresi linear sederhana pada variabel penerimaan kekerasan dalam pacaran menunjukkan bahwa variabel ini memiliki pengaruh signifikan positif antara penerimaan kekerasan dalam pacaran dengan dating violence victimization. Dengan kata lain, semakin tinggi nilai penerimaan kekerasan dalam pacaran, maka semakin tinggi dating violence victimization begitupun sebaliknya. Artinya apabila seseorang memiliki penerimaan kekerasan dalam pacaran yang positif maka akan semakin rentan menjadi korban (victim) pada kekerasan dalam pacaran. Penerimaan kekerasan dalam pacaran yang positif ditandai dengan sikap menerima, pembenaran, dan toleransi seseorang dalam kekerasan (Foshee dkk., 2001; O’Keefe, 1998 dalam Kaura \& Lohman, 2007). Hasil penelitian ini pun sesuai dengan 
penelitian yang dilakukan oleh Malik dan kawan-kawan (1997, dalam Karlsson dkk., 2016) yang menghasilkan remaja yang melaporkan penerimaan kekerasan dalam pacaran positif cenderung melaporkan sebagai perpetrator ataupun victim dari kekerasan dalam pacaran. Selajutnya penelitian yang dilakukan Orpinas dkk., (2013) menunjukkan hal yang serupa dengan penelitian ini yaitu jika penerimaan kekerasan dalam pacaran negatif maka dating violence victimization akan semakin tidak rentan.

Hasil dari uji regresi linear berganda. Dari hasil uji tersebut dapat disimpulkan bahwa kedua variabel independen yaitu self-esteem dan penerimaan kekerasan dalam pacaran masing-masing berpengaruh terhadap variabel dependen dating violence victimization secara simultan dengan self-esteem memilki angka negatif dan penerimaan kekerasan dalam pacaran memiliki angka positif. Di mana penerimaan kekerasan dalam pacaran memiliki pengaruh lebih kuat daripada variabel self-esteem terhadap dating violence victimization. Artinya self-esteem dan penerimaan kekerasan dalam pacaran secara bersamaan dapat mempengaruhi kerentanan terjadinya dating violence victimization, di mana apabila seseorang memiliki self-esteem yang negatif dan penerimaan kekerasan dalam pacaran positif akan lebih rentan menjadi korban (victim) pada kekersan dalam pacaran. Kaura \& Lohman (2009) di hasil penelitiannya mengenai adanya pengaruh penerimaan kekerasan dalam pacaran terhadap dating violence victimization menyarankan penelitian selanjutnya untuk meneliti tingkat self-esteem karena individu yang memiliki tingkat self-esteem yang positif mampu memisahkan diri dari viktimisasi dan tidak menyamakannya dengan masalah dengan siapa dirinya. Selain itu penelitian yang meneliti baik penerimaan kekerasan dalam pacaran dan self-esteem telah menemukan kedua variabel ini signifikan mempengaruhi kekerasan dalam pacaran bersamaan dan secara terpisah (Foshee dkk., 1992; Katz dkk., 2002; Stith dan Farlet, 1993 dalam Kaura \& Lohman, 2009).

Hasil dari analisis yang dilakukan dalam penelitian ini sejalan dengan penelitian-penelitian terdahulu yang sebelumnya sudah dibahas dalam skripsi ini (Aguilar \& Nightingale, 1994; Foshee, 2004; Karlsson dkk., 2016; Kaura \& Lohman, 2009; Murray, 2000; O’Keefe \& Treister, 1998; Orpinas dkk., 2013; Putri, 2012) di mana self-esteem dan penerimaan kekerasan dalam pacaran menjadi alasan mengapa perempuan sulit meninggalkan hubungan yang disertai dengan kekerasan, dan juga mendukung terjadinya dating violence victimization. Salah satu contoh dari hasil penelitian terdahulu adalah sebagai berikut, Price dkk. (1999, dalam Karlsson dkk. 2018) juga menjelaskan remaja dan dewasa muda yang pernah berada dalam hubungan pacaran kekerasan lebih menerima kekerasan dalam pacaran dibandingkan dengan individu tanpa pengalaman tersebut. Kemudian Murray (2000) menjelaskan selfesteem memengaruhi berapa lama korban akan membiarkan dirinya berada di hubungan yang disertai kekerasan. Sehingga dapat dikatakan self-esteem dan penerimaan kekerasan dalam pacaran memiliki pengaruh secara signifikan terhadap dating violence victimization baik secara parsial ataupun simultan sehingga hipotesis dalam penelitian ini terpenuhi.

\section{S I M P U L A N}

Berdasarkan hasil penelitian yang sudah dilakukan, kesimpulannya adalah self-esteem dan penerimaan kekerasan dalam pacaran terdapat pengaruh signifikan secara parsial ataupun simultan dari kedua variabel independen self-esteem dan dating violence victimization terhadap penerimaan kekerasan dalam pacaran pada remaja perempuan, hal ini ditunjukkan dengan angka pengaruh 4,6\% dari selfesteem dan 6,6\% dari penerimaan kekerasan dalam pacaran. Pengaruh dari self-esteem bersifat negatif yang berarti semakin self-esteem positifnya maka semakin tidak rentan dating violence victimizationnya. Sedangkan pengaruh penerimaan kekerasan dalam pacaran memiliki sifat yang positif sehingga berarti apabila penerimaan kekerasan dalam pacaran seseorang semakin positif, maka dating violence victimization-nya. Apabila melihat pengaruh kedua variabel independen self-esteem dan penerimaan 
kekerasan dalam pacaran terhadap dating violence victimization secara simultan, dari hasil analisis menunjukkan bahwa terdapatnya pengaruh secara simultan.

Saran untuk penelitian selanjutnya adalah perlu untuk mengembangkan alat ukur penerimaan kekerasan dalam pacara, karena melihat literasi mengenai penerimaan kekerasan dalam pacaran terbatas, terutama di Indonesia. Saran untuk korban kekerasan dalam pacaran, adalah untuk lebih aware karena self-esteem dan penerimaan kekerasan dalam pacaran dapat mempengaruhi viktimisasi, sehingga diharapkan untuk lebih aware mengenai kedua faktor ini, korban harus memiliki self-esteem yang positif dan penerimaan kekerasan dalam pacaran yang negatif agar semakin rentan terhadap dating violence victimization. Saran untuk praktisi viktimisasi kekerasan, ketika memberikan pelayanan dapat melihat faktor-faktor yang menyebabkan kerentanan viktimisasi dalam kekerasan tersebut, dan dapat menjadi acuan untuk mengembangkan intervensinya.

\section{U C A P A N T ERIMAKASIH}

Terima kasih peneliti ucapkan kepada Allah SWT, keluarga, teman-teman, dan partisipan penelitian ini yang sudah mendukung dan membantu penyelesaian penelitian ini.

\section{DEKLARASI POTENSI TERJADINYAKONFLIK KEPENTINGAN}

Andi Sabrina Qamarani Bachtair dan Nurul Hartini tidak bekerja, menjadi konsultan, memiliki saham, atau menerima dana dari perusahaan atau organisasi manapun yang mungkin akan mengambil untung dari diterbitkannya naskah ini.

\section{PUSTAKA ACUAN}

Aguilar, R. J., \& Nightingale, N. N. (1994). The impact of specific battering experiences on the self-esteem of abused women. Journal of Family Violence, 9(1), 35-45. https://doi.org/10.1007/BF01531967

Cascardi, M., \& Jouriles, E. N. (2018). Mechanisms underlying the association of exposure to family of origin violence and adolescent dating violence. In Adolescent Dating Violence: Theory, Research, and Prevention. Elsevier Inc. https://doi.org/10.1016/B978-0-12-811797-2.00007-4

Fatah, N. A. (2020). Hubungan Antara Self-Esteem dan Pola Asuh Dengan Fear of Intimacy Pada Dewasa Awal. Skripsi.

Foshee, V. A. (2004). Adolescent Dating Violence Do Adolescents Follow in Their Friends', or Their Parents', Footsteps? Journal of Interpersonal Violence, 19(2), 162-184. https://doi.org/10.1177/0886260503260247

Gómez-López, M., Viejo, C., \& Ortega-Ruiz, R. (2019). Well-Being and Romantic Relationships: A Systematic Review in Adolescence and Emerging Adulthood. International Journal of Environmental Research and Public Health, 16(13), 2415. https://doi.org/10.3390/ijerph16132415

Karlsson, M. E. (2011). Predicting dating violence victimization among college women: The role of

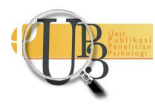


previous exposure to violence and acceptance of dating violence. ProQuest Dissertations and Theses, 158.

http://search.proquest.com/docview/864742194?accountid=14553\%5Cnhttp://openurl.library .uiuc.edu/sfxlcl3?url_ver=Z39.88-

2004\&rft_val_fmt=info:ofi/fmt:kev:mtx:dissertation\&genre=dissertations+\&+theses\&sid=ProQ:P roQuest+Dissertations+\&+Theses+Full+Text\&atitl

Karlsson, M. E., Calvert, M., Hernandez Rodriguez, J., Weston, R., \& Temple, J. R. (2018). Changes in acceptance of dating violence and physical dating violence victimization in a longitudinal study with teens. Child Abuse and Neglect, 86(August), 123-135. https://doi.org/10.1016/j.chiabu.2018.09.010

Karlsson, M. E., Temple, J. R., Weston, R., \& Le, V. D. (2016). Witnessing Interparental Violence and Acceptance of Dating Violence as Predictors for Teen Dating Violence Victimization. Violence Against Women, 22(5), 625-646. https://doi.org/10.1177/1077801215605920

Kaura, S. A., \& Lohman, B. J. (2007). Dating violence victimization, relationship satisfaction, mental health problems, and acceptability of Violence: A comparison of men and women. Journal of Family Violence, 22(6), 367-381. https://doi.org/10.1007/s10896-007-9092-0

Kaura, S. A., \& Lohman, B. J. (2009). Does acceptability of violence impact the relationship between satisfaction, victimization, and commitment levels in emerging adult dating relationships? Journal of Family Violence, 24(6), 349-359. https://doi.org/10.1007/s10896-009-9234-7

Komnas Perempuan. (2020). Kekerasan meningkat: Kebijakan penghapusan kekerasan seksual untuk membangun ruang aman bagi perempuan dan anak perempuan. Catahu: Catatan Tahunan Tentang Kekerasan Terhadap Perempuan, 1-109. https://www.komnasperempuan.go.id/file/pdf_file/2020/Catatan Tahunan Kekerasan Terhadap Perempuan 2020.pdf

Mendoza, M., \& Mulford, C. (2018). Relationship dynamics and teen dating violence. National Institute of Justice. Research in Brief., 14. https://www.ncjrs.gov/pdffiles1/nij/251031.pdf

Murray, J. (2000). But I Love Him. Protecting Your Teen Daughter from Controlling, Abusive Dating Relationships.

O’Keefe, M., \& Treister, L. (1998). Victims of Dating Violence Among High School Students. Are The Predictors Different for Males and Females? Violence Against Women. http://hjb.sagepub.com.proxy.lib.umich.edu/content/9/2/183.full.pdf+html

Orpinas, P., Hsieh, H. L., Song, X., Holland, K., \& Nahapetyan, L. (2013). Trajectories of Physical Dating Violence from Middle to High School: Association with Relationship Quality and Acceptability of Aggression. Journal of Youth and Adolescence, 42(4), 551-565. https://doi.org/10.1007/s10964012-9881-5

Papadakaki, M., Tzamalouka, G. S., Chatzifotiou, S., \& Chliaoutakis, J. (2009). Seeking for risk factors of 
Intimate Partner Violence (IPV) in a greek national sample: The role of self-esteem. Journal of Interpersonal Violence, 24(5), 732-750. https://doi.org/10.1177/0886260508317181

Pereira, M. E., Azeredo, A., Moreira, D., Brandão, I., \& Almeida, F. (2020). Personality characteristics of victims of intimate partner violence: A systematic review. Aggression and Violent Behavior, 52(September 2019), 101423. https://doi.org/10.1016/j.avb.2020.101423

Putri, Y. Z. (2012). Hubungan Antara Kekerasan dalam Pacaram dan Self Esteem pada perempuan dewasa muda (The relationship between dating violence and self esteem on young women ). 1955, 1-20.

Rasyidayanti, A. (2018). PENGARUH HARGA DIRI KONTINGEN DALAM RELASI (RELATIONSHIP CONTINGENT SELF-ESTEEM) PADA PERILAKU KEKERASAN DALAM PACARAN DITINJAU DARI SKRIPSI Disusun Oleh : ARIFAH RASYIDAYANTI. Skripsi.

Rosenberg, M. (1965). Society and the adolescent self-image. Society and the Adolescent Self-Image, 1326. https://doi.org/10.2307/2575639

Santrock, J. (2012). Life-Span Development. McGraw-Hill Education.

Trifiani, N. R. (2012). Pengaruh Gaya Kelekatan Romantis Dewasa (Adult Romantic Attachment Style) terhadap Kecenderungan untuk Melakukan Kekerasan Dalam Pacaran. 1(02), 74-83. 